\title{
Microfluidic guillotine reveals multiple timescales and mechanical modes of wound response in Stentor coeruleus
}

\author{
Kevin S. Zhang ${ }^{1 \dagger}$, Lucas R. Blauch ${ }^{1 \dagger}$, Wesley Huang ${ }^{2}$, Wallace F. Marshall ${ }^{3}$ and Sindy K. Y. Tang ${ }^{1 *}$ (D)
}

\begin{abstract}
Background: Wound healing is one of the defining features of life and is seen not only in tissues but also within individual cells. Understanding wound response at the single-cell level is critical for determining fundamental cellular functions needed for cell repair and survival. This understanding could also enable the engineering of single-cell wound repair strategies in emerging synthetic cell research. One approach is to examine and adapt selfrepair mechanisms from a living system that already demonstrates robust capacity to heal from large wounds. Towards this end, Stentor coeruleus, a single-celled free-living ciliate protozoan, is a unique model because of its robust wound healing capacity. This capacity allows one to perturb the wounding conditions and measure their effect on the repair process without immediately causing cell death, thereby providing a robust platform for probing the self-repair mechanism.
\end{abstract}

Results: Here we used a microfluidic guillotine and a fluorescence-based assay to probe the timescales of wound repair and of mechanical modes of wound response in Stentor. We found that Stentor requires $\sim 100-1000 \mathrm{~s}$ to close bisection wounds, depending on the severity of the wound. This corresponds to a healing rate of $\sim 8-$ $80 \mathrm{\mu m}^{2} / \mathrm{s}$, faster than most other single cells reported in the literature. Further, we characterized three distinct mechanical modes of wound response in Stentor: contraction, cytoplasm retrieval, and twisting/pulling. Using chemical perturbations, active cilia were found to be important for only the twisting/pulling mode. Contraction of myonemes, a major contractile fiber in Stentor, was surprisingly not important for the contraction mode and was of low importance for the others.

Conclusions: While events local to the wound site have been the focus of many single-cell wound repair studies, our results suggest that large-scale mechanical behaviors may be of greater importance to single-cell wound repair than previously thought. The work here advances our understanding of the wound response in Stentor and will lay the foundation for further investigations into the underlying components and molecular mechanisms involved.

Keywords: Microfluidics, Single-cell, Wound healing, Cellular guillotine, Stentor coeruleus

\footnotetext{
* Correspondence: sindy@stanford.edu

${ }^{\dagger}$ Kevin S. Zhang and Lucas R. Blauch contributed equally to this work.

${ }^{1}$ Department of Mechanical Engineering, Stanford University, Stanford, CA 94305, USA

Full list of author information is available at the end of the article
}

(C) The Author(s). 2021 Open Access This article is licensed under a Creative Commons Attribution 4.0 International License, which permits use, sharing, adaptation, distribution and reproduction in any medium or format, as long as you give appropriate credit to the original author(s) and the source, provide a link to the Creative Commons licence, and indicate if changes were made. The images or other third party material in this article are included in the article's Creative Commons licence, unless indicated otherwise in a credit line to the material. If material is not included in the article's Creative Commons licence and your intended use is not permitted by statutory regulation or exceeds the permitted use, you will need to obtain permission directly from the copyright holder. To view a copy of this licence, visit http://creativecommons.org/licenses/by/4.0/ The Creative Commons Public Domain Dedication waiver (http://creativecommons.org/publicdomain/zero/1.0/) applies to the data made available in this article, unless otherwise stated in a credit line to the data. 


\section{Background}

Wound repair is a fundamental property of life. It is an essential biological process for maintaining homeostasis and, ultimately, for survival. While wound repair is known to occur at the tissue level, there is increasing recognition that single cells also have a wound response. Single-cell wound repair has been reported in fungi, amoebae, budding yeast, and also the Metazoa [1-3]. Understanding wound repair at the single-cell level is thus critical for elucidating important cellular functions for homeostasis and survival across the kingdoms of life, and ultimately for developing therapeutic approaches for wound-induced diseases [1].

From a different angle, the ability to engineer singlecell wound repair strategies can find use in emerging synthetic cell research. Recent years have witnessed an explosion in research on building synthetic cells [4-6], not only as an experimental method to study the origins and the rules of life, but also as a new approach to biochemical engineering, in which molecules (e.g., enzymes) are encapsulated in membranes to increase local concentrations and regulate substrate/product exchange, leading to significant increases in the yield and specificity of reactions [7, 8]. Nevertheless, current synthetic cell research has largely neglected one of the most fundamental properties of living matter-the ability to self-repair following damages. If such self-repairing capability can be introduced in synthetic cells, it could open new realms of biochemical engineering by allowing the synthetic cell systems to operate robustly under the potentially harsh environment of industrial processes.

One approach to attaining self-repairing synthetic cells is to adapt self-repair mechanisms from a living system that already demonstrates robust capacity to heal from large mechanical wounds within a single cell, and build analogs of these mechanisms inside synthetic cells. One of such systems is Stentor coeruleus, a single-celled freeliving ciliate protozoan. Our rationales for studying wound healing in Stentor are as follows: (1) Its wound healing capacity is more robust than most other cells (see details in Table 1). Stentor possesses a highly polyploid macronucleus such that even small cell fragments, as small as $1 / 27^{\text {th }}$ of original cell size, can contain enough genomic copies to survive and regenerate in $24 \mathrm{~h}$ $[18,19]$. This unique wound healing property allows us to perturb the wounding conditions and measure their effect on the repair process without immediately causing cell death, thereby providing a robust platform for probing the self-repair mechanism. (2) The ability to perform high-throughput gene knockdown and wounding experiments. We recently sequenced the Stentor genome [20] and developed tools for molecular manipulation of Stentor gene expression [21], thus paving the way to a molecular understanding of Stentor wound repair.

Previous studies of single-cell wound response in organisms such as Xenopus oocytes and Drosophila embryos have indicated that the healing of plasma membrane wounds involves active cellular processes. At least two steps are involved when the plasma membrane is disrupted: (1) the influx of calcium ions through the membrane opening triggers the sealing of the plasma membrane via active trafficking of internal membranes to the wound site, and (2) active remodeling of the cytoskeleton [1, 22-24]. In some organisms, the latter process involves actin accumulation around the wounds and the formation of a contractile purse string, as well as the recruitment of Rho to the plasma membrane and the subsequent active actin assembly at sites of Rho activation [25-27].

Currently, it is unknown whether Stentor also employs similar processes to heal wounds. As Stentor is a ciliate with cellular structures that are distinct from the organisms that have been studied previously for single-cell repair, it is possible that Stentor utilizes different approaches to repair wounds. Longitudinally cut Stentor (cut along the long axis of the cell) have been reported to fold over themselves, though it was not regarded as a general wound response

Table 1 Summary of wound repair timescales in single cells

\begin{tabular}{|c|c|c|c|c|c|}
\hline Cell type & Wound diameter $(\mu \mathrm{m})$ & Cell diameter $(\mu \mathrm{m})$ & $\begin{array}{l}\text { Ratio of wound } \\
\text { diameter to cell } \\
\text { diameter }\end{array}$ & $\begin{array}{l}\text { Healing } \\
\text { time (s) }\end{array}$ & $\begin{array}{l}\text { Approx. healing } \\
\text { rate }\left(\mu \mathrm{m}^{2} / \mathrm{s}\right)\end{array}$ \\
\hline LHCN skeletal muscle (human) [9] & 1 & $\sim 40$ & 0.03 & 70 & 0.01 \\
\hline HeLa [10] & $2-3$ & 30 & 0.07 & $200-300$ & $0.01-0.03$ \\
\hline 3 T3 fibroblast [11] & 2 & 18 & 0.11 & $60-120$ & $0.02-0.05$ \\
\hline Dictyostelium [12] & $0.5-2$ & 15 & 0.03 & $5-10$ & $0.02-0.6$ \\
\hline Drosophila embryo [13] & $12-20$ & $150-500$ & 0.08 & $100-200$ & $0.6-3.1$ \\
\hline Xenopus oocyte [14] & $\sim 200$ & 1200 & 0.17 & 600 & 52 \\
\hline Sea urchin egg [15-17] & $10-50$ & 80 & $0.125-0.625$ & $3-15$ & $31-130$ \\
\hline Stentor coeruleus & $\begin{array}{l}\sim 100 \\
\text { (approximate size of a } \\
\text { single large wound) }\end{array}$ & $\begin{array}{l}\sim 200 \\
\text { (for a cell fragment approx. } \\
\text { half the original cell size) }\end{array}$ & 0.5 & $100-1000$ & 7.9-79 \\
\hline
\end{tabular}


[28]. In addition, cytoplasm spilled outside a wounded Stentor has been observed to flow back into the cell body [29]. However, neither of these phenomena was further characterized. Structurally, Stentor is covered in cilia for locomotion. It consists of an oral apparatus with a dense membranellar band of cilia around the anterior of the cell for feeding. It possesses a holdfast, an anchoring structure, at its posterior. The cell cortex is defined by the oral apparatus and the holdfast, together with ciliated stripes that run parallel to the long axis of the organism. Electron micrographs of Stentor revealed that the ciliated stripes consist of rows of cortical fibers comprising two primary types of filaments, the KM fibers and myonemes [30]. KM fibers are made up of bundles of microtubules and are attached to the cell membrane via basal bodies. Myonemes, located immediately under the KM fibers, are contractile fibers responsible for the rapid contraction of the cell from an extended trumpet shape to a sphere at rates up to 10-20 $\mathrm{cm} / \mathrm{s}$, usually in response to an external stimulus such as poking with a glass needle [31, 32]. Immunostaining of Stentor showed the localization of a protein that is immunologically related to centrin/caltractin, a class of EFhand calcium binding proteins that form contractile filaments in a variety of organisms, in myonemes [33]. Further details on the anatomy of Stentor can be found in previous work [28].

In this paper, we aim to quantify the healing time and characterize the wound response in Stentor inflicted with mechanical wounds from a microfluidic "guillotine". Previously, we have developed a microfluidic guillotine for high throughput wounding and bisection of Stentor cells in a continuous flow manner [34]. Changing the applied flow velocity changes the local cutting dynamics and leads to two regimes of cell bisection: Regime 1 at low viscous stress where cells are cut cleanly with little cytoplasm spillage during the cut, membrane ruptures localized to one side of the cell fragment, and high viability ( 97\%), and Regime 2 at high viscous stress where cells are torn with extensive membrane ruptures and decreased viability ( $60-80 \%)$. See Additional File 1: Fig. S1a-b for examples of cells cut in Regime 1 and 2. While laser ablation allows more exact control of wound size and location compared with our method, it requires immobilizing Stentor which has been challenging since Stentor tends to swim away or rapidly contract into a sphere upon laser excitation (even without being wounded). The continuous flow design of our guillotine circumvents this issue while also allowing us to probe the wound healing characteristics of a large number of cells from seconds to hours after the cells are wounded. Combined with a fluorescence-based assay to detect the presence or absence of a wound, we show that Stentor takes $\sim 100-1000 \mathrm{~s}$ to heal bisection wounds, and we characterize three mechanical modes of wound response that occur in wounded Stentor. The prevalence of these three mechanical modes of wound response in Stentor suggests that mechanical behaviors such as cellular force generation and motility could play a more important role in the single-cell wound repair process than previously thought. This work is expected to lay the foundation for further investigations on the molecular mechanisms of wound repair in Stentor.

\section{Results}

Design of the wound repair assay using a parallelized microfluidic guillotine device and Sytox Green staining

To study the wound repair process in Stentor coeruleus, we designed our microfluidic device with 8 parallelized guillotine channels arranged in a radial geometry converging at a single outlet. This design reduced the distance each cell had to travel and the corresponding lag time prior to assaying the cells. Figure $1 \mathrm{~A}$ shows a schematic diagram of our parallelized guillotine device. The cell suspension was injected via a cell inlet (constant flow rate of 8 and $36 \mathrm{~mL} / \mathrm{h}$ corresponding to an average velocity of 1.4 and $6.3 \mathrm{~cm} / \mathrm{s}$ per guillotine for Regimes 1 and 2, respectively). A flushing inlet was used to inject cell media (Pasteurized Spring Water, PSW) only and was connected directly to the outlet to control the lag time prior to assaying the cells (see details in the "Controlling wound repair time prior to fixation and staining" section). In the microfluidic guillotine, the long axis of the cell was always aligned parallel to the flow and the cell was always aligned either head-first or tail-first. Therefore, the guillotine always bisected the cell longitudinally parallel to the KM fibers.

Our wound repair assay involved 4 steps (Fig. 1B): (i) injecting the cells into the guillotine and wounding them, (ii) collecting the wounded cells via an outlet tubing, (iii) fixing the cells, and (iv) staining the fixed cells with Sytox Green followed by fluorescence imaging to determine if the wound was open or closed. In the time $t_{\text {post-wound }}$ between cell wounding at the guillotine and when the cells were fixed (i.e., the duration of step ii), wounded cells had the opportunity to repair their wounds. By varying $t_{\text {post-wound }}$ (see details in the "Controlling wound repair time prior to fixation and staining" section), we expected to assess the completeness of wound repair as a function of time. In this work, we varied $t_{\text {post-wound }}$ from $4 \mathrm{~s}$ up to $150 \mathrm{~min}$. The lower limit was set by the minimum tubing length that could be used practically in our experiment and the highest flow rate we could apply without further wounding the cells. Our results (Fig. 1E-H) indicated that this timing resolution was sufficient to capture the wound repair dynamics, which occurred over hundreds of seconds.

As no membrane dye to date has worked for staining the plasma membrane of Stentor, we developed an indirect assay to estimate the completion of wound repair by 

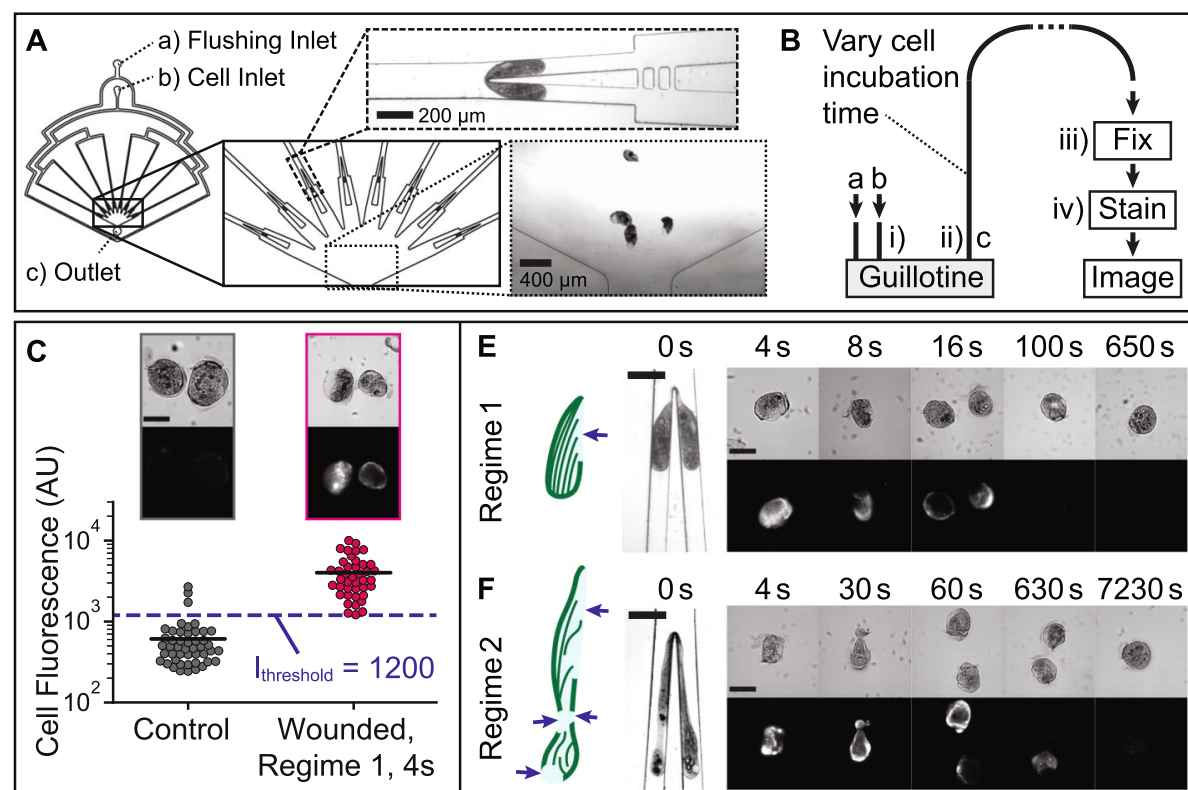

D

G

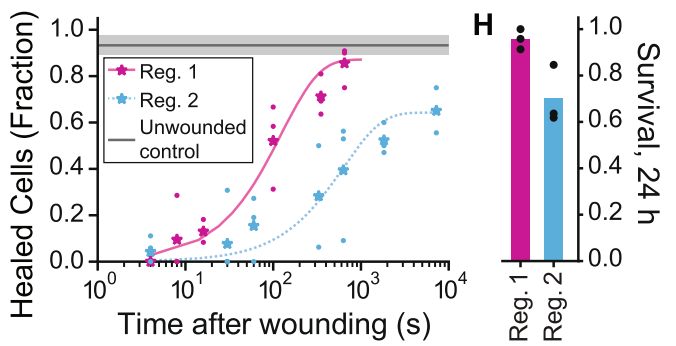

Fig. 1 Wound repair assay design and characterization of wound repair in Stentor coeruleus. A Parallelized guillotine device, with inlets (a) and (b) used for injecting media and cells, respectively, and outlet (c). To parallelize cell cutting, 8 radially arranged guillotines converged in a well leading to outlet (c). B Schematic diagram of the wound repair assay. (a), (b), and (c) refer to the inlets/outlets. (i-iv) are steps in the assay (see Methods). C Cell fluorescence for unwounded cells (controls) $(N=46$ cells) and wounded cells (Regime 1, 4 s post-wounding) ( $N=41$ cells), using the wound repair assay. Data combined from 3 biological replicates per experimental group, with mean lines shown. Representative brightfield and fluorescence images shown. The dashed line at cell fluorescence $=1200$ AU indicates the / threshold used to distinguish wounded from healed cells. D ROC (receiver operating characteristic) curve for the wound repair assay. Representative images of cells wounded in $\mathbf{E}$ Regime 1 and $\mathbf{F}$ Regime 2: illustration of typical wound locations (arrows) in a cut cell fragment (left panel), brightfield (top panels), and corresponding fluorescence images (bottom panels) of wounded cells, fixed and stained with Sytox Green at different time points post-wounding. All fluorescence images were scaled equally (100-10,000 AU). Scale bars in $\mathbf{C}, \mathbf{E}$, and $\mathbf{F}$ are $200 \mu \mathrm{m}$. G Fraction of cells healed, using the wound repair assay. Data shown as mean (stars) of $N \geq 3$ biological replicates (dots) and fit to a one-phase exponential function using mean datapoints in addition to the $24-\mathrm{h}(86,400 \mathrm{~s})$ survival rate, to aid extrapolation. The control line shows the mean fraction of unwounded control cells below /threshold, and the shaded region indicates standard deviation (SD) (3 biological replicates). Total $N=31-65$ cells per experimental condition. $\mathbf{H}$ Survival rate of cells wounded in Regimes 1 and 2, $24 \mathrm{~h}$ after wounding, shown as mean (bar) of 3 biological replicates (dots) $(N=22-34$ cells per replicate)

measuring the fluorescence intensity of a cellimpermeable dye Sytox Green inside a wounded cell. Sytox Green is commonly used to stain nucleic acids in dead cells, which have permeabilized membranes [3537]. We found that on fixed Stentor cells, Sytox Green stained wounded cells, likely due to the presence of nucleic acids (RNA) in the cytosol of Stentor, but did not stain unwounded control cells. Figure 1C shows that the mean fluorescence intensity of wounded cells ( $4 \mathrm{~s}$ after their wounding) was approximately 10 times higher than that of the unwounded control cells. Sytox also sometimes brightly stained the macronucleus (DNA) of highly wounded cells. Although this indirect approach cannot give an absolute measurement of the wound size, the presence or absence of fluorescence could still indicate the presence or absence of a wound. It can thus be used for the binary classification of cells that were unwounded or completely repaired, versus those that were still wounded and thus permeable to Sytox Green at the time of the fixing step. Using a threshold intensity of 1200 (arbitrary units, AU), we were able to distinguish wounded cells from unwounded ones with $100 \%$ sensitivity and $94 \%$ specificity (Fig. 1D). 
Cells wounded in Regime 2 took longer to heal than those wounded in Regime 1

Figure 1E, F show representative images of cells being cut at the guillotine, along with fluorescence images of Sytox staining in representative cell fragments at different $t_{\text {post-wound }}$ in Regimes 1 and 2 respectively. To quantify the wound healing results, we used the mean fluorescence intensity threshold $I_{\text {threshold }}$ of 1200 (arbitrary units) for classifying healed cells vs. wounded cells (Fig. 1C), and plotted the fraction of cells healed as a

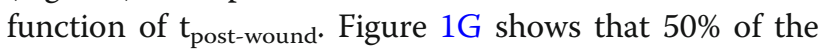
cells cut in Regimes 1 and 2 healed in about $100 \mathrm{~s}$ and $1000 \mathrm{~s}$, respectively. We report the mean percentage of cells healed at each $t_{\text {post-wound }}$ from at least 3 independent biological replicates. The individual fluorescence intensities of Sytox stained cells at different time points are shown in Additional File 1: Fig. S2. In each regime, the maximum percentage of cells healed as measured using the wound repair assay (Fig. 1G) plateaued to a value consistent with the survival rate of cells measured at $24 \mathrm{~h}$ after wounding (Fig. $1 \mathrm{H}$ ).

Immunofluorescence images of acetylated tubulin on cell fragments revealed more details on the damage to the cytoskeleton of the wounded cells (Fig. 2b, c) compared with unwounded cells (Fig. 2a). As the KM fibers, which are microtubule structures arranged in cortical rows, are positioned directly under the cell membrane (within $\sim 1 \mu \mathrm{m}$ [30]), the absence of immunostaining of acetylated tubulin (red arrowheads) could indicate a wound to both the membrane and the cortex, though it has to be verified using Sytox staining. The discontinuities or misalignment in the cortical rows of microtubules indicate that the membrane wound could be closed but the cortical rows had not been reorganized to restore the normal orientation.

Overall, the tubulin staining images showed similar trends as the Sytox staining images. For example, cells cut in Regime 1 did not have any observable gaps in their cortical rows by $t_{\text {post-wound }}=10 \mathrm{~min}$, consistent with the lack of fluorescence in the Sytox staining at that time point. The wounds at earlier time points appeared to be localized to one distinct location. On the other hand, cells cut in Regime 2 had multiple gaps in their cortical rows at $t_{\text {post-wound }}=4$ and $100 \mathrm{~s}$, suggesting that there could be multiple wound sites. In addition, the misalignment in the cortical rows was more severe compared with those in Regime 1. The oral apparatus of the cell, which was stained very brightly by the immunofluorescence of acetylated tubulin, was often observed in multiple pieces over the cell or was completely absent (Additional File 1: Fig. S1). Additional examples of wounded cells and tubulin staining are shown in Additional File 1: Fig. S1.

\section{Mechanical modes of wound response}

Unlike most single-cell wound healing models studied previously, Stentor use their motile cilia to achieve a high degree of motility [28]. By observing cells after wounding, we identified a range of cell motions, which could be grouped into three mechanical modes of wound response (see Additional Files 2, 3, 4 and 5: Movies S1a d). These modes of wound response were events and behaviors that occurred after a cell had been wounded and may assist the cell in repairing large wounds.

\section{Contraction}

A contraction wound response was observed in cells with a wound localized to one side of the cell. The cell contracted or folded around the wound site to reduce the wound size (Fig. 3a). Contraction often involved a decrease in cell length, an increase in cell width, and/or a curling of the cell towards the side containing the wound. Due to the limited resolution of our imaging setup, we considered contraction complete when the wound diameter was reduced to $\sim 20 \mu \mathrm{m}$. Contraction typically took $\sim 100-250 \mathrm{~s}$. When complete, the cells appeared
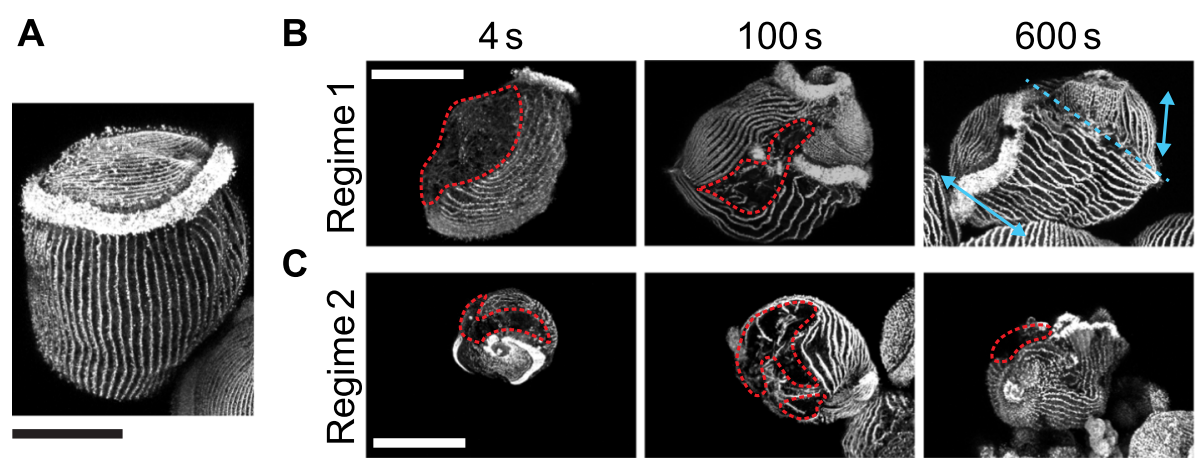

Fig. 2 Immunostaining of acetylated tubulin. a Representative immunostaining image of KM fibers in an unwounded cell. b Representative immunostaining images of KM fibers in cells wounded in Regime 1. Red lines outline the possible location of a wound. The dashed blue line in the healed cell at 10 min indicates the possible location of folding, as seen by the discontinuity in the KM fibers on either side of this line (blue arrows). c Representative immunostaining images of KM fibers in cells wounded in Regime 2. All fluorescence images were acquired on the inverted confocal microscope. All scale bars $100 \mu \mathrm{m}$ 

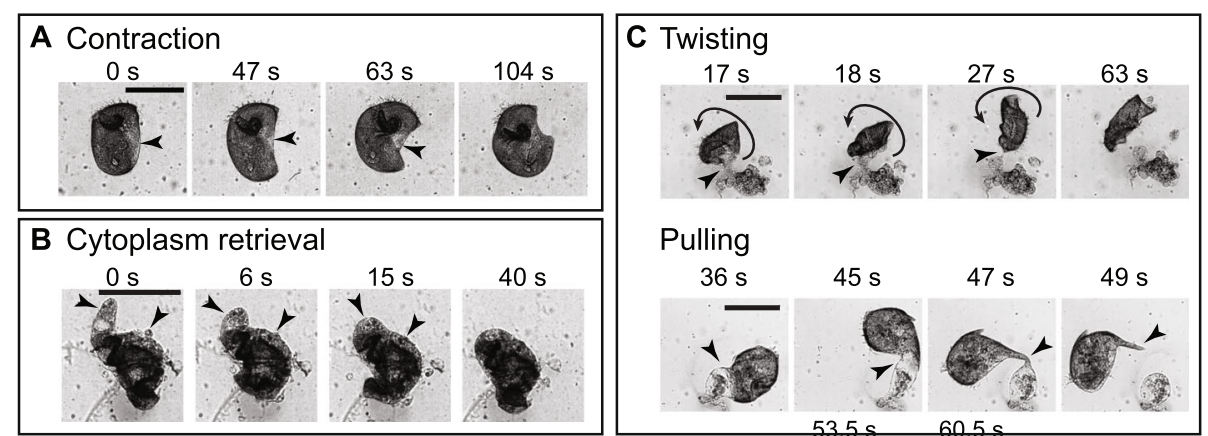

Fig. 3 Mechanical modes of wound response. a Representative images of a cell wounded in Regime 1 undergoing contraction. The arrows point to the location of the wound. $\mathbf{b}$ Representative images of a cell wounded in Regime 2 undergoing cytoplasm retrieval. The arrows point to the retrieved cytoplasm that is part of the wound. c Representative images of cells wounded in Regime 2 utilizing twisting/pulling. The short arrows point to the location of the wound, while the curved arrow indicates the direction of twisting. To better visualize the response in four panels, we did not include images at the beginning of cell twisting/pulling. All scale bars $200 \mu \mathrm{m}$

folded. Additional File 1: Fig. S3 details the analysis of the contraction mode. The contraction wound response was distinct from the rapid contraction observed when unwounded cells were poked with a glass needle.

The effects of the folding behavior observed during contraction could also be seen in the immunostaining of acetylated tubulin. The discontinuity in cortical rows (indicated by the blue arrows and dashed line in Fig. $2 \mathrm{~b}, t_{\text {post-wound }}=$ $10 \mathrm{~min}$; additional images in Additional File 1: Fig. S1), where the bottom set of cortical rows appeared perpendicular to the set at the top-right, is consistent with the cell folding onto itself to close the wound. We found that contraction occurred in more than $80 \%$ of the cells observed in Regime $1(N=22 / 26$ cells $)$, as Regime 1 tended to generate single, localized wounds. While less common in Regime 2, contraction still occurred in $\sim 20 \%$ of cells observed $(N=6$ / 31 cells), only when the wound was localized to one side of the cell like in Regime 1 . However, wounding was typically more severe in Regime 2 than in Regime 1, with multiple wounds observable to the eye and a larger amount of extruded cytoplasm, which may have prevented the contraction mode from occurring.

\section{Cytoplasm retrieval}

We also observed cells retrieving extruded cytoplasm into the cell (Fig. 3b). The retrieval of cytoplasm appeared to follow a change in the shape of the cell. The retrieval process took $\sim 20-200 \mathrm{~s}$. In Regime 1, cytoplasm retrieval occurred in about $50 \%$ of the cells observed $(N=14 / 26$ cells) and often occurred together with contraction $(N=$ $11 / 26$ cells). Cytoplasm retrieval often occurred prior to or during the contraction response mode. Cytoplasm retrieval occurred in about $35 \%$ of the cells observed in Regime $2(N=11 / 31$ cells). Regime 2 cells tended to have more extruded cytoplasm than those in Regime 1 and typically did not retrieve all of the extruded cytoplasm like they did in Regime 1. Instead, some cytoplasm separated during the retrieval process and remained as debris.

\section{Twisting/pulling}

We found that Stentor also used twisting/pulling motions to facilitate wound closure. For cells with large amounts of spilled cytoplasm (especially in Regime 2), part of their extruded cytoplasm could become immobilized on the substrate, and twisting and pulling motions were often observed to detach the cell from its lost cytoplasm (Fig. 3c).

In the twisting mode, the less wounded part of the cell, which still contained beating cilia, repeatedly rotated and resulted in the twisting and eventual pinching of the wound site, thereby freeing the cell from the extruded cytoplasm. In the pulling mode, the more intact part of the cell was observed to swim and pull away from the extruded cytoplasm without twisting. The pulling motion formed a thin fiber at the point of detachment. At times, these thin fibers were seen to fold back over the rest of the cell.

Twisting/pulling response modes typically completed in $\sim 20-100 \mathrm{~s}$. We rarely observed twisting/pulling response modes in cells wounded in Regime 1 ( $N=1 / 26$ cells). In Regime 2 where cells had more extensive wounds, twisting/pulling response modes became more common and occurred in about $60 \%$ of the cells $(N=18 / 31$ cells), occasionally with either contraction or cytoplasm retrieval. In cells that used the twisting/pulling mode, the pulling mode $(N=15 / 19$ cells) occurred more often than twisting $(N=8 / 19$ cells), with 4 cells utilizing both modes.

Among all the cells observed here, cells that had extruded cytoplasm always utilized cytoplasm retrieval, twisting/pulling, or both. Finally, we note that we did not observe any cell utilizing all three modes during the wound response. $5 \%$ of cells in Regime $1(N=1 / 26$ cells) and $10 \%$ of cells in Regime $2(N=3 / 31$ cells) were observed to not utilize any mechanical modes in their wound response. 
Effect of chemical perturbations on wound response To identify cellular components or factors contributing to the mechanical modes of wound response, we investigated the effects of two chemical agents, nickel chloride $\left(\mathrm{NiCl}_{2}\right)$ and potassium iodide (KI), which were previously reported to inhibit cilia motion in Tetrahymena and Paramecium by inhibiting axonemal dynein [38, 39] and myoneme contraction in Stentor [28] respectively. $\mathrm{NiSO}_{4}$, another $\mathrm{Ni}^{2+}$ salt, was reported to have inhibitory effects on Stentor cilia [28].

We measured the spatiotemporal coordination of the cilia in the membranellar band to evaluate the effects of our drug treatments and to test whether wounding affected cilia beating. In unwounded and untreated control cells, the beating cilia bundles on the membranellar band (Fig. 4a) produced metachronal waves that appeared in the 2D autocorrelations as parallel lines (Fig. 4a-c, Additional File 6: Movie S2a, see details in the "Measurement of cilia activity" section). These lines corresponded to a mean wave propagation speed of $1.09 \pm 0.14$ (standard deviation) $\mathrm{mm} / \mathrm{s}$ and cilia beat frequency of $\sim 22.9 \pm 3.7 \mathrm{~Hz}$ ( $N=6$ cells). Upon wounding in Regime 2, the membranellar band of untreated control cells continued to beat in a coordinated fashion at similar speed and frequency as the unwounded case, with a mean wave propagation speed of $\sim 1.17 \pm 0.32$ $\mathrm{mm} / \mathrm{s}$ and cilia beat frequency of $\sim 21.3 \pm 7.0 \mathrm{~Hz}(N=6$ cells) (Fig. 4b, c, Additional File 7: Movie S2b). We always measured cilia beating and coordination at the membranellar band. Because the cells were always cut head-first or tail-first, the membranellar band was always broken during the cut. Our measurements of the membranellar band cilia were, therefore, close to the wound site, rather than far away from it (Additional File 7: Movie S2b). We note that right at the wound site where the cell membrane was lost, the cilia were also lost.

First, we tested the effect of $\mathrm{NiCl}_{2}$ treatment. We verified that $\mathrm{NiCl}_{2}$ treatment suppressed cilia beating in unwounded cells $(N=6$ cells) and that the suppression persisted after wounding ( $N=6$ cells), evidenced by a lack of motion in the kymograph and the absence of a clear wave pattern in the 2D autocorrelation (Fig. 4b, c, Additional File 8-9: Movies S2c - d). Accordingly, the twisting/pulling mode of wound response was less frequently observed in $\mathrm{NiCl}_{2}$-treated cells $(\sim 20 \%$ in Regime 2, $N=6 / 29$ cells) compared with untreated cells $(\sim 60 \%$ in Regime 2, $N=18 / 31$ cells) (Fig. 4e). When a twisting/ pulling mode occurred in a $\mathrm{NiCl}_{2}$-treated cell, it took significantly longer $(\sim 3$ times longer) for the wounded cell to detach itself from the extruded cytoplasm compared to untreated cells $(p=0.0006)$ (Fig. 4 d). $\mathrm{NiCl}_{2}$ treatment had an insignificant effect on the other modes of wound response, contraction $(p=0.84)$, and cytoplasm retrieval $(p=0.84)$. These results indicated that cilia motion was primarily responsible for the twisting and pulling motions. Compared to $\sim 10 \%$ of Regime 2 untreated control cells, $\sim 30 \%$ of Regime $2 \mathrm{NiCl}_{2}$-treated cells $(N=9 / 29$ cells $)$ did not appear to utilize a mechanical mode of wound response. In Regime 2, while the wound healing time as assessed by the wound repair assay remained $\sim 1000 \mathrm{~s}$ (Fig. $4 \mathrm{f}$ ), the average $\mathrm{NiCl}_{2}$ treated cell survival rate was greatly reduced to $20 \%$ (Fig. $4 \mathrm{~g}$ ), compared to $70 \%$ for untreated cells (Fig. $1 \mathrm{H}$ ). The survival of unwounded $\mathrm{NiCl}_{2}$-treated cells was not affected $\left(100 \%\right.$ survival) (Fig. $4 \mathrm{~g}$ ). The average $\mathrm{NiCl}_{2}$ treated cell survival rate in Regime 1 was $67 \%$ compared to $96 \%$ for untreated cells (Fig. $4 \mathrm{~g}$ and $1 \mathrm{H}$ ), which was a lesser reduction in survival rate than seen in Regime 2. Surprisingly, in Regime 1, the wound healing time for $\mathrm{NiCl}_{2}$-treated cells, as assessed by the wound repair assay, increased significantly from $\sim 100$ to $\sim 1000 \mathrm{~s}$ (Fig. 4f), which may have been due to off-target effects or toxicity of $\mathrm{Ni}^{2+}$. The individual fluorescence intensities of Sytox stained cells at different time points are shown in Additional File 1: Fig. S2. Overall, these results supported that cilia motion was a crucial component for the wound repair process in Stentor.

To further investigate whether the twisting/pulling response was a byproduct of the spilled cytoplasm binding to the solid substrate, we collected wounded cells into an aqueous droplet suspended on a fluorinated oil (with a density of $1855 \mathrm{~kg} / \mathrm{m}^{3}$ ). The spilled cytoplasm did not adhere to this liquid-liquid (L-L) interface formed between water and oil (Additional File 1: Fig. S4a). We note that typical surface treatments to block binding (e.g., coating with BSA, Pluronic F-68) were not successful in blocking the large amounts of spilled cytoplasm from adhering to the glass and PDMS microfluidic device. In the L-L system, we found that most untreated cells that had large amounts of spilled cytoplasm were still able to complete twisting/pulling response modes $(N=16$ out of 17 cells that had large amounts of spilled cytoplasm), but took approximately 3 times longer than untreated cells in the microfluidic device did $(p=0.0055)$ (Additional File 1: Fig. $\mathrm{S} 4 \mathrm{~b})$. The survival rates of untreated cells, wounded or unwounded, in the L-L system were similar to those in the solid-liquid (S-L) system where the cells were collected in a polystyrene petri dish (Additional File 1: Fig. S4c).

In $\mathrm{NiCl}_{2}$-treated cells, twisting/pulling was seen less frequently when cells were collected in the L-L system $(N=1$ out of 19 cells that had large amounts of spilled cytoplasm) compared to cells in the microfluidic device (Additional File 1: Fig. S4b). The survival of $\mathrm{NiCl}_{2}$ treated, Regime 2 wounded cells was similar in S-L and L-L systems $(p=0.3403)$. However, the survival of $\mathrm{NiCl}_{2}$-treated unwounded and Regime 1 wounded cells were both lower in the L-L system than in the S-L system. (Additional File 1: Fig. S4c). 

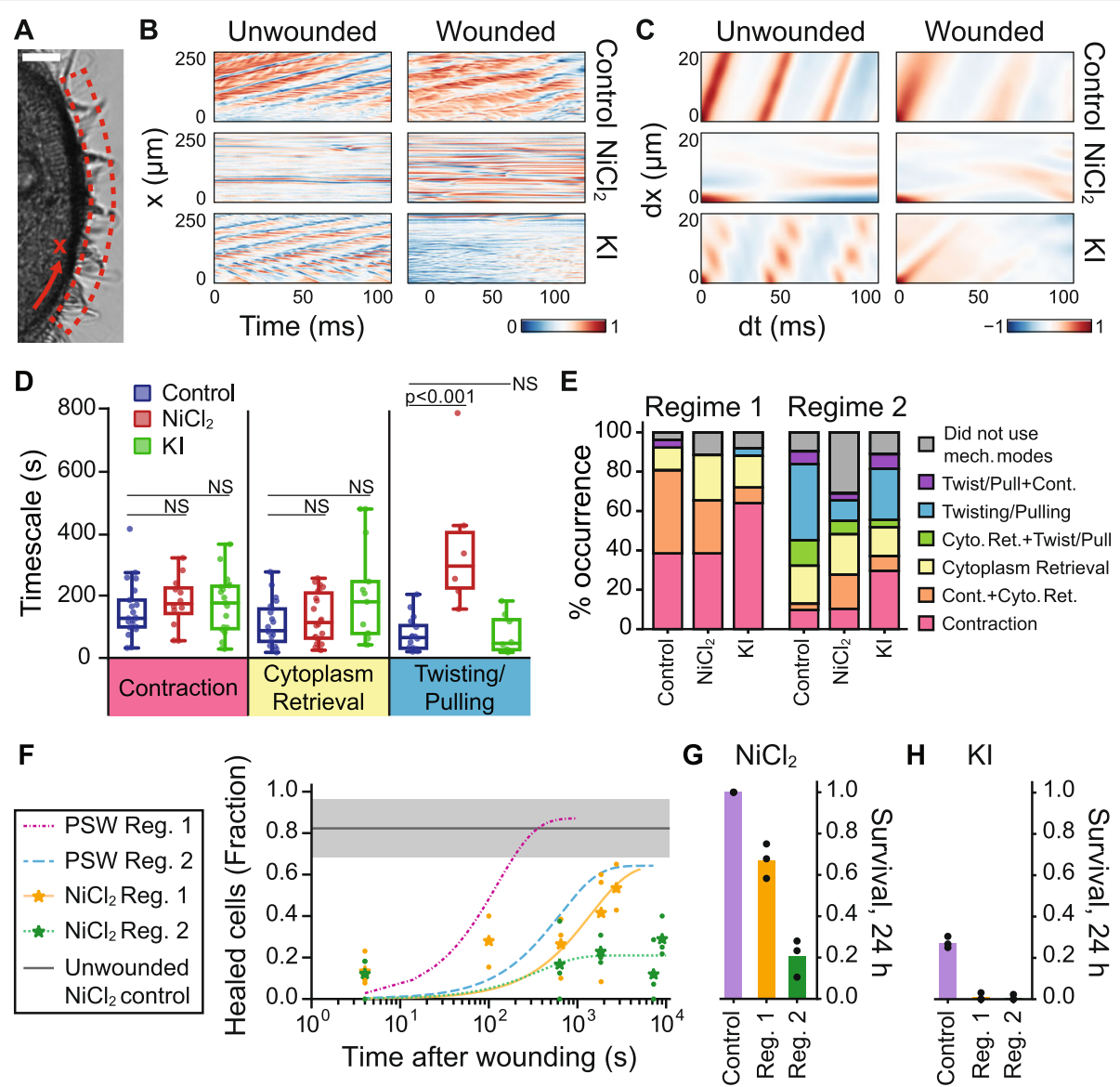

Fig. 4 Effect of chemical perturbations on wound response. a Region of interest and 1-D coordinate system defined along the membranellar band. Scale bar $20 \mu \mathrm{m}$. b Kymographs and c 2-D autocorrelations of the kymographs for cells under control (no treatment), $\mathrm{NiCl}{ }_{2}$, or $\mathrm{KI}$ treatment, before and after wounding in Regime 2. Analysis of representative cells shown ( $N=6$ per experimental group). $\mathbf{d}$ Measured timescales of mechanical modes of wound response in untreated control (PSW), NiCl 2 -treated, and Kl-treated cells, shown as box and whisker plots with a line at the median. Data in each treatment condition combined from Regimes 1 and 2; individual cells shown as dots (control: $N=16-21$ cells per mode; $\mathrm{NiCl}_{2}$ : N =6-22 cells per mode; $\mathrm{Kl}: \mathrm{N}=8-19$ cells per mode). Timescales were measured as described in the "Imaging of cell motion after wounding" section. Significance values were obtained from multiple $t$ tests for treated cells compared to untreated cells, $a=0.05$. Only the $\mathrm{NiCl}_{2}-$ treated twisting/pulling timescale was significantly different from that of untreated cells $(p=0.0006)$. All other timescales were not significantly different (NS, $p>0.05$ ). e Relative occurrences of mechanical modes of wound response across wounding regime and treatment condition (Total $N=25-31$ cells per experimental group). $\mathbf{f}$ Fraction of $\mathrm{NiCl}_{2}$-treated cells healed, using the wound repair assay. Data shown as mean (stars) of $\mathrm{N} \geq$ 3 biological replicates (dots) and fit to a one-phase exponential function using mean datapoints in addition to the $24-h$ ( 86,400 s) survival rate, to aid extrapolation. Untreated (PSW) curves included for comparison. The control line shows the mean fraction of unwounded $\mathrm{NiCl}_{2}$-treated control

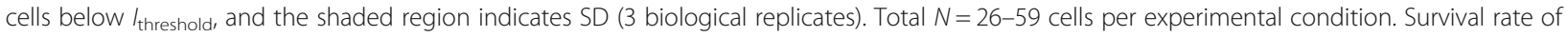
$\mathbf{g ~ N i C l}$-treated cells and $\mathbf{h}$ Kl-treated cells. Data for unwounded control cells, $24 \mathrm{~h}$ after washing, and Regime 1 or 2 wounded cells, $24 \mathrm{~h}$ after wounding, shown as mean (bar) of 3 biological replicates (dots) $(N=15-47$ cells per replicate)

Second, we tested the effect of KI treatment. Poking untreated and unwounded cells with a glass needle induced rapid cell contraction within $\sim 20 \mathrm{~ms}[28,31,32,40]$. We verified that unwounded KI-treated cells failed to contract upon poking, suggesting that myoneme contraction was successfully inhibited (Additional Files 10 and 11: Movies S3a - b). The survival rate of KI-treated cells was very low-about 25\% for unwounded control cells and $0 \%$ for Regime 1 and 2 cells (Fig. 4h), which precluded the use of our wound repair assay on KI-treated cells (all cells were washed following the KI treatment). The membranellar band of unwounded KI-treated cells remained active and beat with a mean wave propagation speed of $\sim 0.91 \pm 0.20$ $\mathrm{mm} / \mathrm{s}$ and cilia beat frequency of $\sim 21.0 \pm 5.2 \mathrm{~Hz}(N=6$ cells), which was not significantly reduced compared to unwounded and untreated control cells (wave speed $p=$ 0.105 ; beat frequency $p=0.47$ ). In KI-treated cells wounded in Regime 2, the membranellar band beat with a mean wave propagation speed of $\sim 1.18 \pm 0.60 \mathrm{~mm} / \mathrm{s}$ and cilia beat frequency of $\sim 21.9 \pm 4.0 \mathrm{~Hz}(N=6$ cells). Compared with the smooth edges in the bands in the 2D autocorrelation of untreated control cells indicating high 
coordination, the bands of KI-treated cells had rough, fuzzy edges and discontinuities, indicating a slight loss of coordination (Fig. 4b, c, Additional Files 12 and 13: Movies S2e - f). We observed that KI treatment intended to inhibit the myonemes could also affect the membranellar band. In about $45 \%$ of KI-treated cells, the membranellar band would be inhibited and no beating was noticeable by eye ( 3 biological replicates, $N=18-24$ cells per replicate). This inhibition could be due to the partial anesthetization of the cilia by potassium ions [41]. Iodide ions may also play a role in membranellar band inhibition, as $\mathrm{NaI}$ has been previously reported to inhibit the membranellar band in Stentor, although KI was not discussed [41]. However, the body cilia of KI-treated cells remained as active as untreated control cells qualitatively, compared with the inactive body cilia of $\mathrm{NiCl}_{2}$-treated cells, in both unwounded and wounded cells $(N=6$ cells for each condition) (Additional File 14: Movie S2g, Additional File 15: Movie S2h). These results verified that KI-treated cells retained actively beating and coordinated cilia.

Figure $4 \mathrm{~d}$ shows that the timescales for all three modes of response in KI-treated cells were insignificantly different from the untreated controls (contraction $p=0.86$; retrieval $p=0.13$; twisting/pulling $p=0.99$ ). In both Regimes 1 and 2, KI-treated cells more often utilized contraction alone in their wound response (Regime 1, $N=16 / 25$ cells; Regime 2, $N=8 / 27$ cells) compared to untreated control cells (Regime $1, N=10 / 26$ cells; Regime $2, N=3 / 31$ cells), while both the cytoplasm retrieval and twisting/pulling modes occurred less often (Fig. 4e). These results indicate that active myonemes are not necessary for the contraction response mode, but may play a role in the cytoplasm retrieval and twisting/pulling modes. Finally, in all treatment cases, both the beating of the membranellar band (measured by the 2D autocorrelation) and the body cilia (qualitatively compared) were not strongly affected by wounding.

\section{Discussions}

\section{Timescale of wound healing}

We have characterized the wound repair time in Stentor subject to mechanical wounds. Comparison of the timescales to heal in Regimes 1 and 2 revealed that Stentor took longer to heal when the wounding was more severe ( $\sim 100$ s vs. $\sim 1000$ s, respectively). The timescale of each of the three mechanical modes of wound response varied from $\sim 20$ to $\sim 250 \mathrm{~s}$ (Fig. $4 \mathrm{~d}$ ), much shorter than $\sim 600 \mathrm{~s}$ for $\sim 90 \%$ of the cells to heal in Regime 1 (Fig. 1G). Because the wound responses characterized here may not necessarily seal the wound, we attribute this difference to the requirement of wound repair mechanisms to fully close the wound, such as vesicle trafficking and fusion with the membrane, and possibly actomyosin purse string, which may be conserved in Stentor due to its use in ciliate cell division [42-44]. Ongoing work is being performed to investigate these wound repair mechanisms but are outside the scope of this paper.

In addition, we note that the variation in the timescale for cells to heal was relatively large even in Regime 1 (from $100 \mathrm{~s}$ where $\sim 50 \%$ of the cells were healed, to $600 \mathrm{~s}$ where $\sim 90 \%$ of the cells were healed). This variation could be due to the variation in the initial cell size (Additional File 1: Fig. S5) and the wound size created by our wounding method, which relied on cell deformation and was thus sensitive to initial cell size. In addition, while the long axis of the cell was always aligned parallel to the flow and the guillotine always bisected the cell longitudinally, we could not control the orientation of the cell and the exact location where the cell was cut. This factor could lead to different types of wounds even in Regime 1, and therefore the relatively large variations in the wound healing time.

\section{Mechanical modes of wound response}

We have described and begun to characterize three distinct mechanical modes of wound response: contraction, cytoplasm retrieval, and twisting/pulling (Fig. 5). Up to 95\% of wounded cells utilized at least one of these mechanical modes, which suggests that the three mechanical modes play an important role in the wound response. While events local to the wound site have been the focus of many single-cell wound repair studies [1], the mechanical modes described here indicate that large-scale mechanical events such as cellular force generation and motility may be of greater importance than previously considered. Because we considered events in the seconds to minutes scale only, we do not expect the regeneration of cellular structures or organelles, which typically takes an hour or longer in Stentor, to have affected the results here. Interestingly, no cell was observed to use all three mechanical modes. It is unknown if this is a consequence of the type and the specific location of wounds the guillotine inflicts upon the cells, or perhaps if one to two mechanical response modes are generally sufficient in the wound repair process. In untreated Regime 2 cells, $\sim 90 \%$ of cells used mechanical modes of wound response $(N=28 / 31$ cells $)$ while only $\sim 70 \%$ survived ( 3 biological replicates, $N=22$ 34 cells per replicate) on average. This suggests that the mechanical modes of wound response may not be sufficient for survival.

Tartar has previously reported cells folding on themselves after being cut longitudinally [28] but no further investigation was performed. Such folding behavior was very similar to the contraction mode we had observed here. The lack of effect on the frequency and timescale of the contraction wound response by $\mathrm{NiCl}_{2}$ and $\mathrm{KI}$ treatment indicate that the process was not mediated by cilia motion or myoneme contraction. The milliseconds timescale of myoneme contraction $[31,32]$ is orders of magnitude shorter than the timescale of the contraction wound response, which further 

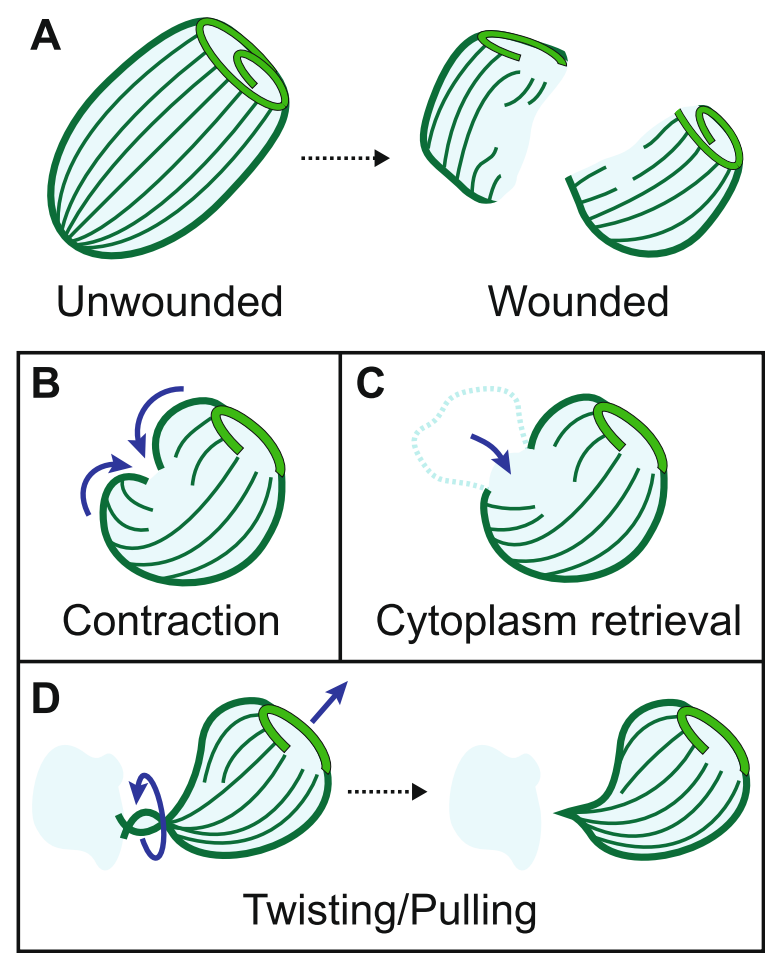

Fig. 5 Overview of mechanical modes of wound response in Stentor. Conceptual illustration of mechanical response modes in Stentor described in this study. a An unwounded cell is bisected into 2 wounded cell fragments using our microfluidic guillotine platform. After wounding, Stentor can potentially use a combination of 3 mechanical response modes to aid in its wound repair: $\mathbf{b}$ contraction, in which the cell folds around the wound site, $\mathbf{c}$ cytoplasm retrieval, in which extruded cytoplasm is pulled back into the cell body, and $\mathbf{d}$ twisting/pulling, in which the cell uses a twisting/pulling motion to detach from extruded cytoplasm. Further work is needed to probe the mechanisms of these wound response modes and to investigate the wound repair mechanisms in Stentor

supports that the contraction wound response is unlikely to be driven by myoneme contraction. On the other hand, the timescale of contraction wound response is similar to the timescale over which cells elongate by microtubule sliding ( 1-2 min) after having undergone myoneme contraction. It is thus possible that microtubule sliding may be involved in the contraction wound response. It is difficult to infer how contraction progresses based on the tubulin staining images. Live Stentor rapidly takes a more spherical shape upon exposure to harsh chemicals such as the fixatives used in tubulin staining, so any apparent wound in the tubulin images may not necessarily be the true shape of the wound in the live cell. More work is necessary to investigate the mechanism underlying such contraction behavior. Apart from microtubules, we were unable to stain for actin or other cortical structures using conventional stains. To identify whether wound recovery was actin or microtubuledependent, we had attempted using pharmacological drugs but with limited success. These drugs are commonly used in mammalian systems, and their effects in ciliates and especially in Stentor are unknown. RNAi experiments could help probe the roles of actin, microtubules, and myoneme fibers, but these experiments are out of scope of the current paper.

In the case where the cytoplasm was extruded outside of the cell, we observed two different responses: cytoplasm retrieval and twisting/pulling. Cytoplasm retrieval has been previously reported in Stentor [29] and was accompanied by extensive cytoplasmic flow that is also observed in unwounded cells. It is unknown whether this cytoplasmic flow is also driving the cytoplasm retrieval as observed here. Alternatively, it is possible that the retrieval is similar to the retraction of a bleb [45-47], where membrane and cortex reform at the boundary of the extruded cytoplasm. The contraction of the cortex then leads to the retraction of the cytoplasm inside the cell. To further probe this mechanism will require a better imaging method to verify the presence of membrane and cortex.

When a large amount of extruded cytoplasm was spilled, especially in Regime 2, the cells typically did not retrieve all of the extruded cytoplasm and instead twisting/pulling responses occurred more often. The twisting/pulling response mode involved the "amputation" of the extruded cytoplasm by cilia-mediated twisting/pulling motions. Wounding did not increase the speed or beating frequency of the membranellar band and did not appear to affect the activity of the body cilia. Thus, the twisting/pulling mode was likely a spontaneous response, rather than a response that is activated from wounding. Further, our results using the liquid-liquid interface show that adhesion to a solid substrate (i.e., where one end of the cell fragment is pinned) is not necessary for twisting/pulling motion, but the presence of a solid substrate significantly reduces the time required for the cell to detach from the spilled cytoplasm. Since the survival of untreated cells was not significantly affected by the liquid-liquid interface, the longer time needed to complete twisting/pulling and detach from the spilled cytoplasm in the absence of pinning was not detrimental to the cell.

We note the remarkable similarity between the twisting wound response and rotokinesis, where the rotation of one half of the dividing cell severs the bridge connecting to the other cell half [43]. Rotokinesis is required for the completion of Tetrahymena cell division [43] and has also been seen in Stentor cell division. Without cilia motion in Tetrahymena, $60 \%$ of the mutant cells failed to complete cytokinesis [43]. Here, Stentor treated with $\mathrm{NiCl}_{2}$ had suppressed cilia motion and failed to detach from the extruded cytoplasm by twisting/pulling motions. The survival of $\mathrm{NiCl}_{2}$ treated cells also plummeted in Regime 2 where twisting/ pulling was a dominant response to wounding. The survival of $\mathrm{NiCl}_{2}$-treated Regime 2 wounded cells in the $\mathrm{L}$ - $\mathrm{L}$ system 
was similar to and as low as that in the S-L system. This result indicates that removal of the cell from the solid substrate alone is insufficient for viability. Rather, the cell needs to be detached from the spilled cytoplasm in order to heal and survive (as seen by the higher survival of Regime 2 wounded cells in untreated vs. $\mathrm{NiCl}_{2}$-treated cells in either $\mathrm{S}-\mathrm{L}$ or L-L systems). This further implies that contraction and/or cytoplasm retrieval was insufficient to recover the cell when the spilled cytoplasm was large. We note that the survival of $\mathrm{NiCl}_{2}$-treated unwounded cells and Regime 1 wounded cells were both decreased in the L-L system compared with the S-L system. We speculate it was due to interfacial tension at the water-oil interface which could damage the cell, as $\mathrm{NiCl}_{2}$-treated cells were unable to swim away from the interface.

The survival of $\mathrm{NiCl}_{2}$-treated cells in Regime 1 also decreased, but not as sharply as in Regime 2. Further, the typical wound repair time increased by an order of magnitude to $\sim 1000 \mathrm{~s}$. This was unusual considering that the twisting/pulling response mode was rare in Regime 1 and that the survival of the control $\mathrm{NiCl}_{2}$-treated cells was $100 \%$. A possible explanation is that $\mathrm{Ni}^{2+}$ ions have other inhibitory effects. $\mathrm{Ni}^{2+}$ ions are known to inhibit axonemal dynein in Paramecium [39]. It is possible that cytoplasmic dynein is also affected in Stentor, but it is currently unclear what role cytoplasmic dynein plays in the wound repair process in Stentor.

KI-treated cells utilized cytoplasm retrieval and twisting/pulling less often than control cells, but the timescales of each mode were not significantly different from untreated control cells, suggesting a relatively minor role of myoneme contraction in these two modes. It is also possible that more heavily injured KI-treated cells (e.g., cells with spilled cytoplasm that would otherwise utilize cytoplasm retrieval and/or twisting/pulling) were more likely to die before a wound response could be observed, and thus be excluded from the experimental results. Although KI treatment had only a slight effect on the mechanical response modes, the survival of wounded KItreated cells and even the control KI-treated cells was very low, $\sim 0$ and $25 \%$, respectively. From these results, it is likely that KI treatment is inhibiting additional cellular processes beyond myoneme contraction, or that $\mathrm{KI}$ is generally cytotoxic to Stentor. Nevertheless, it was worthwhile to test the effects of KI treatment on the immediate wound response, as currently no suitable alternative is known to robustly inhibit myoneme contraction without significantly affecting cilia function, and the composition of the myonemes is not yet fully identified $[33,41]$.

\section{Comparison to other single-cell models}

We estimated that both the wound repair rate and the maximum wound size that can be repaired in Stentor were among the largest in the single cells studied thus far (Table
1). Many of the other cell types studied exist in vivo as part of tissues, where a low wound repair capacity in individual cells may not be detrimental as there are other approaches to close the tissue-level wound such as cell migration and proliferation [24]. As a free-living unicellular organism, Stentor cannot rely on neighboring cells for assistance to survive and repair wounds. In this regard, the ability of Stentor to survive large open wounds for extended periods of time is an enormous biological advantage, e.g., in surviving predator attacks, and a remarkable biophysical phenomenon. Two features of Stentor that may contribute to this ability are of notable interest. The first is the contractile vacuole complex which periodically expels excess fluid and ions from the cell [48], a function that may be crucial in maintaining homeostasis in the presence of an open wound. The second is the massive length scale of Stentor cells. Because of their large size, Stentor may have relatively larger amounts of material reserves available to mount a wound response. Further, cell damage resulting from diffusive loss of essential biomolecules and influx of excess ions will occur on orders of magnitude slower timescales than in small cells only a few micrometers in size.

\section{Conclusions}

In summary, we have quantified the healing time and characterized three mechanical modes of wound response in Stentor inflicted with mechanical wounds from a microfluidic guillotine. At least one mechanical mode was observed in almost all injured cells, which highlights the role of large-scale mechanical behaviors that may be crucial to single-cell wound repair. Chemical perturbations revealed the critical role of cilia-mediated twisting/ pulling motion in wound response, and that myoneme contraction was marginally involved in the three mechanical modes observed. The modes of wound response characterized here are behaviors that occur as part of the cell's response upon wounding and may facilitate the overall wound repair process in Stentor. However, the active mechanisms driving the closure of the plasma membrane remain to be investigated.

\section{Methods}

\section{Stentor cell culture}

Stentor coeruleus were cultured in Pasteurized Spring Water (PSW) (132458, Carolina Biological Supplies) in 400 $\mathrm{mL}$ Pyrex dishes in the dark at room temperature. In a modification to standard Stentor culture [49], Stentor were fed Chlamydomonas every 2 days (see Additional File 1: Note S1 for details). Prior to each experiment, healthy adult cells $(\sim 400 \mu \mathrm{m}$ in diameter and dark green in color) were retrieved from culture by pipetting under a stereoscope into a 4-mL glass vial. A cell suspension (density $\sim 0.5$ cells per $\mu \mathrm{L}$ ) was obtained by sucking cells from the glass vial into tubing attached to a syringe filled with cell media (PSW). 
Cells were injected into the microfluidic guillotine for wounding experiments.

\section{Microfluidic guillotine design, fabrication, and wounding experiments}

The master mold of the microfluidic device was fabricated in SU-8 on a silicon wafer using standard photolithography. The height of the master was measured with a profilometer to be $100 \mu \mathrm{m}$. A second replica mold of the master mold was made from Smoothcast 310 using a technique described previously [50]. Poly (dimethylsiloxane) (PDMS) (SYLGARD-184 ${ }^{\text {rm }}$, Dow Corning) was then cured from either the original or secondary mold, following standard soft lithography procedures, and bonded to a glass slide to form the final device. The device was left overnight at $65^{\circ} \mathrm{C}$ in an oven prior to use in order to strengthen the adhesion between PDMS and glass and to make the channel hydrophobic. Prior to use, the channels were washed with a small amount of ethanol in order to remove air bubbles from the channel. Afterwards, at least $1 \mathrm{~mL}$ of cell media was injected to clean the channels. Given the dimensions of our channels, the use of less than $1 \mathrm{~mL}$ of cell media could lead to improper cell cutting. Channels were washed from the outlet with cell media between separate experiments and discarded if cell debris or residues could not be removed from the channel.

A syringe pump was used to inject the cell suspension into the microfluidic guillotine (inlet (b), Fig. 1A, B) at constant flow rates of $8 \mathrm{~mL} / \mathrm{h}$ for Regime 1 and $36 \mathrm{~mL} / \mathrm{h}$ for Regime 2 respectively. These flow rates corresponded to an average velocity of $1.4 \mathrm{~cm} / \mathrm{s}$ and $6.3 \mathrm{~cm} / \mathrm{s}$ respectively at each guillotine. Cell media was injected via inlet (a) (Fig. 1A, B) at various flow rates to control the wound repair time (see the "Controlling wound repair time prior to fixation and staining" section).

\section{Controlling wound repair time prior to fixation and staining}

We controlled the duration between the time when cells were wounded and when they were fixed ( $t_{\text {post-wound }}$ ) using two methods.

-1) $t_{\text {post-wound }}<30 \mathrm{~s}$. We varied the length of the outlet tubing (BB31695-PE/4, Scientific Commodities Inc.) from 4 to $25 \mathrm{~cm}$ with a constant cross-section area of $0.454 \mathrm{~mm}^{2}$.

- The cell suspension was injected into the device via inlet (b) at the flow rates listed above. In Regime 1, cell media was also simultaneously injected via inlet (a) at $10 \mathrm{~mL} / \mathrm{h}$ to increase the velocity of cells exiting the outlet (c) to $18 \mathrm{~mL} / \mathrm{h}$ total, so to decrease the lag time before assaying the cells. Increasing the flow rate at the outlet also prevented cells from sticking to the tubing, increasing the accuracy of $t_{\text {post-wound. }}$ $\circ$ Additional File 1: Note S2 details how $t_{\text {post-wound }}$ was calculated.

-2) 1 min $<t_{\text {post-wound }}<120 \mathrm{~min}$. We varied the incubation time of the cells inside the tubing. The outlet tubing length was standardized $(25 \mathrm{~cm})$ and was prefilled with cell media and went into an empty $2-\mathrm{mL}$ Eppendorf tube. A constant volume of cell suspension $(110 \mu \mathrm{L}$ for Regime 1 , and $70 \mu \mathrm{L}$ for Regime 2) was injected via inlet (b) into the microfluidic guillotine device at the flow rates listed above. Note that inlet (a) was not used at this time, but was connected to a syringe to prevent backflow into inlet (a).

$\circ$ After the fixed volume of cell suspension was injected, a timer was started immediately. The majority of wounded cells were inside the outlet tubing, and cells that remained in the device were not fixed or stained.

o When the timer went off, corresponding to the desired incubation time prior to fixation and staining, we pumped $250 \mu \mathrm{L}$ of cells into $1 \mathrm{~mL}$ of fixing solution from the flushing inlet (inlet (a)) at $18 \mathrm{~mL} / \mathrm{h}$ (for both Regime 1 and 2 experiments). By flushing with inlet (a), which went directly to the outlet, we omitted any cells which were not already in the tubing after wounding. Note that inlet (b) was not used at this time, but had a syringe hooked up to it that prevented backflow into inlet (b).

$\circ$ Additional File 1: Note S2 details how $t_{\text {post-wound was }}$ calculated.

\section{Fixation protocol and wound repair assay}

Extreme care was taken in all steps to minimize cell wounding during handling and fixation. We used a fixing solution of $1 \%$ formaldehyde (no methanol) (43368, Alfa Aesar) and 0.025\% Triton X-100 (X100-100ML, Sigma Life Sciences) in PSW at room temperature. To fix the cells, $250 \mu \mathrm{L}$ of wounded cells was ejected from the guillotine device and the outlet tubing using a syringe pump (see details above) into $1 \mathrm{~mL}$ of the fixing solution in a 2$\mathrm{mL}$ round-bottomed tube (111568, Globe Scientific) and incubated for $10 \mathrm{~min}$ at room temperature. The round bottom aided in the collection of cells while avoiding significant clumping. The tubing was submerged in the fixation solution and did not contact the bottom of the 2-mL tube to avoid additional cell wounding.

To stain the wounded cells, we used Sytox Green (S7020, Invitrogen) at a concentration of $2.5 \mu \mathrm{M}$ in PSW at room temperature. After fixation, we used a $200-\mu \mathrm{L}$ pipette tip with the end cut off at the $20 \mu \mathrm{L}$ line to transfer $50 \mu \mathrm{L}$ of the cells from the bottom of the fixation tube to a $500 \mu \mathrm{L}$ solution of Sytox in a 4-mL glass vial with a flat bottom (C4015-21, ThermoScientific). A flat 
bottom vial, rather than a rounded or conical bottom vial, was used to ensure all cells were exposed evenly to Sytox as cells did not pellet in the flat bottom vial. After 30 min of incubation in Sytox, we washed $50 \mu \mathrm{L}$ of the stained cells in $500 \mu \mathrm{L}$ of PSW in a second 4-mL glass vial, and then transferred $50 \mu \mathrm{L}$ of washed cells onto a No. 1 glass slide using a $200 \mu \mathrm{L}$ pipette tip with the end cut off at the $20 \mu \mathrm{L}$ line. If we could not capture all cells in the $50 \mu \mathrm{L}$ volume, additional $50 \mu \mathrm{L}$ volumes were put onto separate glass slides to avoid wounding the cells already on the slide and to avoid increasing the background signal due to additional media volume on the slide. To minimize cell adhesion and damage due to shear, tubing and pipette tips used to handle wounded cells were treated with 3\% Pluronic F-68 (J6608736, Alfa Aesar) in deionized (DI) water for $3 \mathrm{~h}$ and then washed.

Cells were then imaged at $\times 15$ magnification on an EMCCD camera (Andor iXon 897, Oxford Instruments) mounted on an epifluorescence microscope with 0.05-s exposure time, a mercury lamp set to ND 1, and a FITC excitation/emission filter set. To quantify the fluorescence of cells stained with Sytox, we manually traced the cells in ImageJ and measured the average pixel intensity of each cell. See Additional File 1: Fig. S6, Note S3 for the complete reagent list and for the details on the optimization of the assay.

Immunostaining of acetylated tubulin to visualize KM fibers To visualize KM fibers in wounded and unwounded cells, we performed immunofluorescence for acetylated tubulin. To begin, we fixed $250 \mu \mathrm{L}$ of cells in $1000 \mu \mathrm{L}$ of ice-cold methanol in a 2-mL plastic tube (16466-060, VWR). For wounded cells, the time post-wounding was controlled following the methods above. Cells were incubated in methanol at $-20^{\circ} \mathrm{C}$ for $40 \mathrm{~min}$. We removed the supernatant and then added $500 \mu \mathrm{L}$ of 1:1 methanol: PBS and incubated for $10 \mathrm{~min}$ at room temperature. We removed the supernatant and then added $500 \mu \mathrm{L}$ of PBS and incubated for $20 \mathrm{~min}$ at room temperature. We removed the supernatant and then and added blocking buffer consisting of $500 \mu \mathrm{L}$ of $2 \%$ BSA $+0.1 \%$ Triton X100 in PBS and incubated for $2 \mathrm{~h}$ at room temperature or overnight at $4{ }^{\circ} \mathrm{C}$. We removed the supernatant and then added $500 \mu \mathrm{L}$ of primary antibody (T7451-200UL, Sigma Life Sciences) diluted 1:1000 in blocking buffer and incubated for $2 \mathrm{~h}$ at room temperature or overnight at $4{ }^{\circ} \mathrm{C}$. We removed the supernatant and then washed 3 times with $500 \mu \mathrm{L}$ of PBS, allowing cells to settle at the bottom of the tube between each wash. We removed the supernatant and then added $500 \mu \mathrm{L}$ of $488 \mathrm{~nm}$ excitation fluorescent secondary antibody (SAB4600388-125UL, Fluka Analytics) diluted 1:1000 in blocking buffer and incubated for $2 \mathrm{~h}$ at room temperature or overnight at $4{ }^{\circ} \mathrm{C}$. We removed the supernatant and then washed 3 times with $500 \mu \mathrm{L}$ of PBS, allowing cells to settle at the bottom of the tube between each wash. We then immediately imaged the cells by pipetting $50 \mu \mathrm{L}$ onto a No. 1 glass slide.

We used two imaging setups for the KM fibers. We obtained confocal images using an inverted laser scanning confocal microscope (Zeiss, LSM 780). Cells were imaged using a $\times 20(\mathrm{NA}=0.8)$ objective at an excitation wavelength of $488 \mathrm{~nm}$, and a broad emission filter matching the spectra of Alexa Fluor 488. We obtained additional epifluorescence images using an EMCCD camera (Andor iXon 897, Oxford Instruments) mounted on an inverted microscope with a $\times 10$ or $\times 20$ objective.

\section{Imaging of cell motion after wounding}

We observed cell behavior in response to a wound using a high-speed camera (Phantom v7.3 or Phantom v341) operating between 20 and 100 fps mounted on an inverted brightfield microscope using a $\times 4, \times 5$, or $\times 10$ objective. Cell response behaviors were observed immediately after cutting, either inside the device in the large well before the outlet, or on top of the PDMS device using No. 1.5 coverslips to create a well with a defined height.

To measure the time for each mechanical mode to complete, we determined the first and last frame the mode could be seen manually. The contraction mode was considered complete when the wound was smaller than $\sim 20 \mu \mathrm{m}$, at which point it was difficult to see consistently with our imaging setup. Although cells could have multiple smaller wounds in addition to a large wound across one side of the cell (especially in Regime 2), we only considered the large wound in evaluating the contraction response. The cytoplasm retrieval mode was considered complete when the cytoplasm did not form an apparent protrusion out of the cell. The twisting/pulling mode was considered complete when the cell completely detached itself from the extruded cytoplasm.

To measure the timescale and frequency of occurrence of different modes of wound response, we only considered cells and behaviors which met the following criteria: (1) The location of wounding was visible with our imaging setup. For example, the wound location would not be visible if it were obscured by the shadow from the device sidewalls or the outlet tubing, or if the cell left the field of view. If we lost visibility of the wound location before the wound response was complete, we would count behaviors that were observed prior to the loss of visibility towards the frequency of occurrence, but would not quantify the timescale of their response. (2) The cell did not swim back into the narrow channels near the guillotine blade during its wound response. Re-entry into these narrow channels 
would deform and compress the cells, possibly leading to additional injury. If a cell entered the narrow channels before its wound response was complete, we would count behaviors that were observed prior to the contact towards the frequency of occurrence, but would not quantify the timescale of their response. (3) Unwounded cells (due to stopping of the pump for observation) were not included. (4) The cell did not die during observation (which typically occurred in the first 5-10 min after wounding). For this experiment, we considered cells dead if they ruptured and lost complete membrane integrity. This type of cell death was only observed for a few cases with KI treatment.

The frequency of each behavior was then calculated by considering cells which met all criteria for that behavior. Some cells used multiple modes, and thus, the frequency of occurrence for the three modes can add up to greater than $100 \%$. For cases where the mechanical response modes were less common, the sum of the frequencies of occurrence can be less than $100 \%$, indicating that not all wounded cells utilized a mechanical response mode.

\section{Survival measurements}

Cell survival after cutting was quantified using Eq. 1:

$$
\text { Survival }=\frac{N_{24 h}}{N_{0 h}}
$$

where $N_{0}{ }_{h}$ is the number of cell fragments counted at the channel outlet at $t=0 \mathrm{~h}$, immediately after the cut, and $N_{24} h$ is the number of live cells $24 \mathrm{~h}$ after the cut. $N_{0} h$ was counted manually from videos of the cutting process. The videos were obtained using the high-speed camera at $100 \mathrm{fps}$ (Regime 1) and at 450 fps (Regime 2) respectively. Immediately after cutting, cell fragments were included in $N_{O} h$ if they were larger than $1 / 4$ of a typical bisected cell cut in Regime 1 and appeared to have a part of an intact cell membrane. $N_{24} h$ was counted manually by examining the cells stored overnight in a 2" Petri dish with $\sim 5 \mathrm{~mL}$ of cell media. At $24 \mathrm{~h}$ after cutting, cells were considered alive and included in $N_{24} h$ if they had beating cilia, were swimming, or were attached to the surface in a trumpet-like shape [34].

\section{Perturbations}

\section{Nickel chloride $\left(\mathrm{NiCl}_{2}\right)$ treatment}

Cilia beating was reversibly inhibited by $\mathrm{NiCl}_{2}$ treatment. We prepared a $100 \mathrm{mM}$ stock solution of $\mathrm{NiCl}_{2 \text { (aq) }}$ (N6136, Sigma) in DI water and gently heated it at $50{ }^{\circ} \mathrm{C}$ until fully dissolved.
Inhibiting cilia beating caused increased adhesion of the cells to the tubing and the microfluidic device. To minimize cell adhesion and damage due to shear, all tubing and microfluidic devices used in the $\mathrm{NiCl}_{2}$ experiments were incubated with 3\% Pluronic F68 in DI water for $3 \mathrm{~h}$ and then washed.

To prepare $\mathrm{NiCl}_{2}$-treated cells, we loaded approximately 15 cells in a $25 \mu \mathrm{M} \mathrm{NiCl}{ }_{2}$ solution in PSW inside a $20-\mathrm{cm}$ length of tubing using a syringe. The tubing was then disconnected from the syringe (to prevent cells from swimming into the syringe barrel before the cilia were fully inhibited) and the cells were incubated for $5 \mathrm{~h}$. Then, the tubing was reconnected to a syringe and prepared device both filled with cell media, taking care to eliminate any air bubbles. From this point onwards, device operation, cell fixing, and Sytox staining proceeded as before. We found this treatment condition was the most effective in inhibiting cilia beating without compromising cell viability. Cilia motion was recovered within $24 \mathrm{~h}$ post-wash.

\section{Potassium iodide (KI) treatment}

We incubated cells in a solution of 1\% KI (60400, Sigma-Aldrich) in PSW for $5 \mathrm{~min}$, followed by washing in PSW. Cells were used within $30 \mathrm{~min}$ after washing. This method has been shown previously to inhibit Stentor contraction [28]. To minimize cell adhesion and damage due to shear, all tubing and microfluidic devices used in the KI experiments were incubated with 3\% Pluronic F68 in DI water for $3 \mathrm{~h}$ and then washed.

\section{Measurement of cilia activity}

High-speed images of the cells were taken at $5000 \mathrm{fps}$ with a $\times 20$ objective using the Phantom v341 camera and analyzed following the method published by Wan et al. [51]. Briefly, points along the membranellar band were manually defined using Image and used to generate a parameterized curve that forms a $1 \mathrm{D}$ coordinate system. For a set of equally spaced points along this parameterized curve, a box centered around each point and aligned normal to the curve defined the region of interest. The mean pixel intensity of each of these boxes was taken to convert the region of interest into a $1 \mathrm{D}$ signal in space, which was then used to compute 2D kymographs of image intensity. Finally, we performed a 2D autocorrelation of the 2D image intensity kymograph, which correlates the kymograph with time- and space-shifted versions of itself. The normalized 2D autocorrelation coefficient $c(\delta t, \delta x)$ for a given shift $(\delta t, \delta x)$ is given by Eq. 2 . 


$$
c(\delta t, \delta x)=\frac{\sum_{t, x}^{t-\delta t, x-\delta x}[f(t, x)-\bar{f}(t, x)][f(t+\delta t, x+\delta x)-\bar{f}(t+\delta t, x+\delta x)]}{\left\{\left\{\sum_{t, x}^{t-\delta t, x-\delta x}[f(t, x)-\bar{f}(t, x)]^{2}\right\}\left\{\sum_{t, x}^{t-\delta t, x-\delta x}[f(t+\delta t, x+\delta x)-\bar{f}(t+\delta t, x+\delta x)]^{2}\right\}\right\}^{0.5}}
$$

where $f(t, x)$ is the image intensity of the cilia at time $t$ and point $x$ and $\bar{f}(t, x)$ is the mean of $f(t, x)$ in the region sampled. Physically, a high $c$ is interpreted to mean that a specific configuration of cilia has reappeared at a time $\delta t$ after the original and at a location $\delta x$ away from the original. This analysis measures how a specific configuration of the cilia travels through time and space along the membranellar band and is an indication of the spatiotemporal coordination of the cilia.

\section{Liquid-liquid interface experiments}

To prevent cytoplasm adhesion to the PDMS and/or glass substrate during the twisting/pulling mode of wound response, we generated a liquid-liquid interface using oil and water. Circular wells approximately $1 \mathrm{~cm}$ in diameter were cut into a $1.5-\mathrm{cm}$-thick slab of PDMS and then the slab was bonded to a glass slide. After bonding, the wells were coated with Aquapel (PGW Auto Glass) to render the PDMS and glass hydrophobic. To generate the liquid-liquid interface, each well was first filled with $250 \mu \mathrm{L}$ of FC-40 oil $(3 \mathrm{M})$. Then, $400 \mu \mathrm{L}$ of PSW was added on top of the denser and immiscible oil to form a suspended droplet. Guillotine operation remained the same as before. Cells were cut and collected into a $25-\mathrm{cm}$-long piece of tubing. The tip of the tubing was inserted into the suspended droplet and approximately $100 \mu \mathrm{L}$ of the cut cells was pushed gently by hand using the syringe attached to inlet (a) to avoid creating large disturbances in the suspended droplet. For the 24-h survival experiments using the liquid-liquid interface, the wells were stored adjacent to reservoirs of oil and covered to slow down evaporation of the oil.

\section{Experimental design and statistical analysis}

Cells used for experiments were always used the second day after feeding to ensure consistency (Additional File 1: Notes S1, S3). At least 3 biological replicates were performed for each experimental group in the wound repair assay experiments. For wound response observation experiments, each independent experiment yielded 1-3 cells for observation, and a total of at least 25 cells were observed for each experimental group. To assess differences in wound response mechanism timescales, we performed statistical analysis using unpaired two-sample $t$ tests with Holm-Sidak correction for multiple comparisons. Values of $p<0.05$ were considered statistically significant. The sample size $N$ in each experiment group is provided in the figure captions. The same batch of reagents was used throughout all experiments to minimize batch to batch variation.

\section{Supplementary Information}

The online version contains supplementary material available at https://doi. org/10.1186/s12915-021-00970-0.

Additional file 1: Figure S1. Additional images of cells post wounding. Figure S2. Measured mean fluorescence of individual cells using the wound repair assay. Figure $\mathbf{S 3}$. Details of cell behavior quantification. Figure S4. Effect of a liquid-liquid interface to prevent cytoplasm adhesion. Figure S5. Cell size variation. Figure S6. Optimization of Sytox Green staining. Note S1. Stentor feeding protocol, optimized for wound repair assay. Note S2. Calculation of wound repair time. Note S3. Wound repair assay optimization. Table $\mathbf{S 1}$. Comparison of different dyes for staining wounded Stentor cells.

Additional file 2. Observation of the contraction wound response in Regime 1.

Additional file 3. Observation of the cytoplasm retrieval wound response in Regime 2.

Additional file 4. Observation of the twisting wound response in Regime 2.

Additional file 5. Two observations of the pulling wound response in Regime 2.

Additional file 6. Membranellar band cilia, unwounded control cell.

Additional file 7. Membranellar band cilia, wounded control cell

Additional file 8. Membranellar band cilia, unwounded $\mathrm{NiCl}_{2}$-treated cell

Additional file 9. Membranellar band cilia, wounded $\mathrm{NiCl}_{2}$-treated cell

Additional file 10. Myoneme contraction in a control cell.

Additional file 11. Myoneme contraction in a Kl-treated cell.

Additional file 12. Membranellar band cilia, unwounded KI-treated cell

Additional file 13. Membranellar band cilia, wounded Kl-treated cell

Additional file 14. Body cilia of unwounded cells.

Additional file 15. Body cilia of wounded cells.

Acknowledgements

We thank the instructors and students of the 2019 Center for Cellular Construction Summer Course for their helpful discussions.

\section{Authors' contributions}

KSZ, LRB, and SKYT designed the experiments; KSZ, LRB, and WH performed the experiments and data analysis. KSZ, LRB, WFM, and SKYT wrote the manuscript. All authors read and approved the final manuscript.

\section{Funding}

The work was supported by the National Science Foundation (NSF Award: 1938109 and 1938102), and in part by the Center for Cellular Construction, which is a Science and Technology Center funded by the National Science Foundation (NSF Award: DBI-1548297), and NIH grant R35 GM130327. Device fabrication was performed in the Stanford Nano Shared Facilities (SNSF).

\section{Availability of data and materials}

The datasets used and/or analyzed during the current study are available from the corresponding author on reasonable request.

Ethics approval and consent to participate Not applicable.

Consent for publication Not applicable. 


\section{Competing interests}

The authors declare no competing interests.

\section{Author details}

'Department of Mechanical Engineering, Stanford University, Stanford, CA 94305, USA. ${ }^{2}$ Department of Biology, San Francisco State University, San Francisco, CA 94132, USA. ${ }^{3}$ Department of Biochemistry and Biophysics, University of California San Francisco, San Francisco, CA 94158, USA.

Received: 5 November 2020 Accepted: 31 January 2021 Published online: 02 April 2021

\section{References}

1. McNeil PL, Steinhardt RA. Plasma membrane disruption: repair, prevention, adaptation. Annu Rev Cell Dev Biol. 2003;19:697-731. https://doi.org/10.114 6/annurev.cellbio.19.111301.140101.

2. Bement WM, Yu H-YE, Burkel BM, Vaughan EM, Clark AG. Rehabilitation and the single cell. Curr Opin Cell Biol. 2007;19:95-100. https://doi.org/10.1016/j. ceb.2006.12.001.

3. Schapire AL, Valpuesta V, Botella MA. Plasma membrane repair in plants. Trends Plant Sci. 2009;14:645-52. https://doi.org/10.1016/j.tplants.2009.09. 004.

4. Noireaux V, Maeda YT, Libchaber A. Development of an artificial cell, from self-organization to computation and self-reproduction. Proc Natl Acad Sci U S A. 2011;108:3473-80. https://doi.org/10.1073/pnas.1017075108.

5. Schwille P, Spatz J, Landfester K, Bodenschatz E, Herminghaus S, Sourjik V, et al. MaxSynBio: avenues towards creating cells from the bottom up. Angew Chem Int Ed Engl. 2018:57:13382-92. https://doi.org/10.1002/anie.2 01802288 .

6. Adamala KP, Engelhart AE, Szostak JW. Collaboration between primitive cell membranes and soluble catalysts. Nat Commun. 2016;7:11041. https://doi. org/10.1038/ncomms 11041.

7. Noireaux V, Libchaber A. A vesicle bioreactor as a step toward an artificial cell assembly. Proc Natl Acad Sci U S A. 2004;101:17669-74. https://doi.org/1 $0.1073 /$ pnas. 0408236101

8. Elani Y, Law RV, Ces O. Protein synthesis in artificial cells: using compartmentalisation for spatial organisation in vesicle bioreactors. Phys Chem Chem Phys. 2015;17:15534-7. https://doi.org/10.1039/c4cp05933f.

9. Carmeille R, Bouvet F, Tan S, Croissant C, Gounou C, Mamchaoui K, et al. Membrane repair of human skeletal muscle cells requires Annexin-A5. Biochim Biophys Acta. 1863;2016:2267-79. https://doi.org/10.1016/j.bbamcr.2 016.06.003.

10. Jimenez AJ, Maiuri P, Lafaurie-Janvore J, Divoux S, Piel M, Perez F. ESCRT machinery is required for plasma membrane repair. Science. 2014;343: 1247136. https://doi.org/10.1126/science.1247136.

11. Togo $T$, Alderton JM, Bi GQ, Steinhardt RA. The mechanism of facilitated cell membrane resealing. J Cell Sci. 1999;112(Pt 5):719-31.

12. Pervin MS, Itoh G, Talukder MSU, Fujimoto K, Morimoto YW, Tanaka M, et al. A study of wound repair in Dictyostelium cells by using novel laserporation. Sci Rep. 2018:8:7969. https://doi.org/10.1038/s41598-018-26337-0.

13. Abreu-Blanco MT, Verboon JM, Parkhurst SM. Cell wound repair in Drosophila occurs through three distinct phases of membrane and cytoskeletal remodeling. J Cell Biol. 2011;193:455-64. https://doi.org/10.1 083/jcb.201011018.

14. Bement WM, Mandato CA, Kirsch MN. Wound-induced assembly and closure of an actomyosin purse string in Xenopus oocytes. Curr Biol. 1999;9: 579-87. https://doi.org/10.1016/s0960-9822(99)80261-9.

15. McNeil PL, Vogel SS, Miyake K, Terasaki M. Patching plasma membrane disruptions with cytoplasmic membrane. J Cell Sci. 2000;113(Pt 11):1891-902.

16. McNeil PL, Kirchhausen T. An emergency response team for membrane repair. Nat Rev Mol Cell Biol. 2005;6:499-505. https://doi.org/10.1038/nrm1665.

17. Terasaki M, Miyake K, McNeil PL. Large plasma membrane disruptions are rapidly resealed by $\mathrm{Ca} 2+-d e p e n d e n t$ vesicle-vesicle fusion events. J Cell Biol. 1997;139:63-74. https://doi.org/10.1083/jcb.139.1.63.

18. Lillie FE. On the smallest parts of Stentor capable of regene ration: a contribution on the limits of divisibility of living matter. J Morphol. 1896;xii: 239-49.

19. Morgan TH. Regeneration of proportionate structures in Stentor. Biol Bull. 1901;2:311. https://doi.org/10.2307/1535709.
20. Slabodnick MM, Ruby JG, Reiff SB, Swart EC, Gosai S, Prabakaran S, et al. The macronuclear genome of Stentor coeruleus reveals tiny introns in a giant cell. Curr Biol. 2017;27:569-75. https://doi.org/10.1016/j.cub.2016.12.057.

21. Slabodnick MM, Ruby JG, Dunn JG, Feldman JL, DeRisi JL, Marshall WF. The kinase regulator mob1 acts as a patterning protein for stentor morphogenesis. PLoS Biol. 2014;12:e1001861. https://doi.org/10.1371/journal. pbio.1001861.

22. Reddy A, Caler EV, Andrews NW. Plasma membrane repair is mediated by Ca (2+)-regulated exocytosis of lysosomes. Cell. 2001;106:157-69. https://doi. org/10.1016/s0092-8674(01)00421-4.

23. McNeil PL, Miyake K, Vogel SS. The endomembrane requirement for cell surface repair. Proc Natl Acad Sci U S A. 2003;100:4592-7. https://doi.org/1 0.1073/pnas.0736739100.

24. Sonnemann KJ, Bement WM. Wound repair: toward understanding and integration of single-cell and multicellular wound responses. Annu Rev Cell Dev Biol. 2011;27:237-63. https://doi.org/10.1146/annurev-cellbio-092910-1 54251.

25. Andrews PD, Stark MJ. Dynamic, Rho1p-dependent localization of Pkc1p to sites of polarized growth. J Cell Sci. 2000;113(Pt 15):2685-93.

26. Delley PA, Hall MN. Cell wall stress depolarizes cell growth via hyperactivation of RHO1. J Cell Biol. 1999;147:163-74. https://doi.org/10.1 083/jcb.147.1.163.

27. Levin DE. Cell wall integrity signaling in Saccharomyces cerevisiae. Microbiol Mol Biol Rev. 2005;69:262-91. https://doi.org/10.1128/MMBR.69.2.262-291.2005.

28. Tartar V. The biology of Stentor. Pergammon. 1961. https://doi.org/10.1016/ C2013-0-01654-4

29. Slabodnick M, Prevo B, Gross P, Sheung J, Marshall W. Visualizing cytoplasmic flow during single-cell wound healing in Stentor coeruleus. J Vis Exp. 2013;:e50848. doi:https://doi.org/10.3791/50848.

30. Huang B, Pitelka DR. The contractile process in the ciliate, Stentor coeruleus. I. The role of microtubules and filaments. J Cell Biol. 1973;57:704-28. https:// doi.org/10.1083/jcb.57.3.704

31. Jones AR, Jahn TL, Fonseca JR. Contraction of protoplasm. 3. Cinematographic analysis of the contraction of some heterotrichs. J Cell Physiol. 1970;75:1-7. https://doi.org/10.1002/jcp.1040750102.

32. Newman E. Contraction in stentor coeruleus: a cinematic analysis. Science. 1972;177:447-9. https://doi.org/10.1126/science.177.4047.447.

33. Maloney MS, McDaniel WS, Locknar SA, Torlina HM. Identification and localization of a protein immunologically related to Caltractin (Centrin) in the Myonemes and Membranelles of the Heterotrich ciliate Stentor coeruleus. J Eukaryot Microbiol. 2005;52:328-38. https://doi.org/10.1111/j.1 550-7408.2005.00048x.

34. Blauch LR, Gai Y, Khor JW, Sood P, Marshall WF, Tang SKY. Microfluidic guillotine for single-cell wound repair studies. Proc Natl Acad Sci U S A. 2017;114:7283-8. https://doi.org/10.1073/pnas.1705059114.

35. Lebaron P, Catala P, Parthuisot N. Effectiveness of SYTOX Green stain for bacterial viability assessment. Appl Environ Microbiol. 1998;64:2697-700.

36. Thakur S, Cattoni DI, Nöllmann M. The fluorescence properties and binding mechanism of SYTOX green, a bright, low photo-damage DNA intercalating agent. Eur Biophys J. 2015;44:337-48. https:/doi.org/10.1007/s00249-015-1027-8.

37. Green LC, LeBlanc PJ, Didier ES. Discrimination between viable and dead Encephalitozoon cuniculi (Microsporidian) spores by dual staining with sytox green and calcofluor white M2R. J Clin Microbiol. 2000;38: $3811-4$

38. Bayless BA, Galati DF, Junker AD, Backer CB, Gaertig J, Pearson CG. Asymmetrically localized proteins stabilize basal bodies against ciliary beating forces. J Cell Biol. 2016;215:457-66. https://doi.org/10.1083/jcb.201604135.

39. Larsen J, Satir P. Analysis of Ni (2+)-induced arrest of Paramecium axonemes. J Cell Sci. 1991;99(Pt 1):33-40.

40. Tang S, Marshall W. Primer: cell learning. Curr Biol. 2018;28:PR1180-4.

41. Tartar V. Reactions of Stentor coeruleus to certain substances added to the medium. Exp Cell Res. 1957;13:317-32. https://doi.org/10.1016/0014-482 7(57)90011-3.

42. Field C, Li R, Oegema K. Cytokinesis in eukaryotes: a mechanistic comparison. Curr Opin Cell Biol. 1999;11:68-80. https://doi.org/10.1016/ s0955-0674(99)80009-X.

43. Brown JM, Hardin C, Gaertig J. Rotokinesis, a novel phenomenon of cell locomotion-assisted cytokinesis in the ciliate Tetrahymena thermophila. Cell Biol Int. 1999;23:841-8. https://doi.org/10.1006/cbir.1999.0480.

44. Jurand A, Selman G g. Anatomy of Paramecium Aurelia. 1st edition. London: Macmillan; 1969. 
45. Woolley TE, Gaffney EA, Goriely A. Membrane shrinkage and cortex remodelling are predicted to work in harmony to retract blebs. R Soc Open Sci. 2015;2:150184. https://doi.org/10.1098/rsos.150184.

46. Young J, Mitran S. A numerical model of cellular blebbing: a volumeconserving, fluid-structure interaction model of the entire cell. J Biomech. 2010;43:210-20. https://doi.org/10.1016/j.jbiomech.2009.09.025.

47. Charras G, Paluch E. Blebs lead the way: how to migrate without lamellipodia. Nat Rev Mol Cell Biol. 2008;9:730-6. https://doi.org/10.1038/ nrm2453.

48. Plattner $\mathrm{H}$. The contractile vacuole complex of protists--new cues to function and biogenesis. Crit Rev Microbiol. 2015;41:218-27. https://doi. org/10.3109/1040841X.2013.821650

49. Lin A, Makushok T, Diaz U, Marshall WF. Methods for the study of regeneration in stentor. J Vis Exp. 2018. https://doi.org/10.3791/57759.

50. Desai SP, Freeman DM, Voldman J. Plastic masters-rigid templates for soft lithography. Lab Chip. 2009;9:1631-7. https://doi.org/10.1039/b822081f.

51. Wan KY, Hürlimann SK, Fenix AM, McGillivary RM, Makushok T, Burns E, et al. Reorganization of complex ciliary flows around regenerating Stentor coeruleus. Philos Trans R Soc Lond B, Biol Sci. 2020;375:20190167. https://doi. org/10.1098/rstb.2019.0167.

\section{Publisher's Note}

Springer Nature remains neutral with regard to jurisdictional claims in published maps and institutional affiliations.

Ready to submit your research? Choose BMC and benefit from:

- fast, convenient online submission

- thorough peer review by experienced researchers in your field

- rapid publication on acceptance

- support for research data, including large and complex data types

- gold Open Access which fosters wider collaboration and increased citations

- maximum visibility for your research: over $100 \mathrm{M}$ website views per year

At BMC, research is always in progress.

Learn more biomedcentral.com/submissions 